Binghamton University

The Open Repository @ Binghamton (The ORB)

The Society for Ancient Greek Philosophy Newsletter

3-27-1987

\title{
Epicurus on Pleasure and Happiness
}

Julia Annas

University of Arizona, jannas@email.arizona.edu

Follow this and additional works at: https://orb.binghamton.edu/sagp

Part of the Ancient History, Greek and Roman through Late Antiquity Commons, Ancient Philosophy Commons, and the History of Philosophy Commons

\section{Recommended Citation}

Annas, Julia, "Epicurus on Pleasure and Happiness" (1987). The Society for Ancient Greek Philosophy Newsletter. 146.

https://orb.binghamton.edu/sagp/146

This Article is brought to you for free and open access by The Open Repository @ Binghamton (The ORB). It has been accepted for inclusion in The Society for Ancient Greek Philosophy Newsletter by an authorized administrator of The Open Repository @ Binghamton (The ORB). For more information, please contact ORB@binghamton.edu. 


\section{Pac 87}

\section{Epicurus on pleasure and happiness}

(First draft)

\section{Julia Annas (University of Arizona)}

Epicurus was, notorious1y, a hedonist. A1so, like a11 other ancient ethical theorists, he took ethics to be about the agent's final good, and held this to be eudaimonia or happiness. What makes his ethics hard to interpret is the fact that our texts do not make it obvious how Epicurus saw the formal structure of his ethics. (1)

A famous passage in the Letter to Menoeceus (129-130) suggests that in seeing pleasure as the agent's final good, Epicurus was setting it up as something the agent should try to maximize in a straightforward way. While all pleasure is good, he says, it is not all to be chosen (and correspondingly for rejecting pain). We pass over pleasures if they bring an increase in further pains, and prefer present pains to present pleasures if this brings an increase in future pleasures. The impression of a proto-Benthamic calculus is strengthened by two points. First1y, we judge these matters by measuring. Secondly, 'we treat the good at some times as evil, and the evil on the other hand as good'. It seems as though, in deciding on each action, we reduce all the relevant factors to pleasure and pain, and measure these so as to maximize overall pleasure. No kind of pleasure is as such always worthy of choice; it can always become 'treated as evil' if it has bad enough consequences. Pleasures seem to be judged, then, by their Benthamic purity and fecundity.

This is at any rate a comprehensible hedonism. But if we take it to be Epicurus', we find ourselves with an ethical theory that at once turns schizophrenic. For Epicurus insists on other theses. We should fulfil only desires whose neglect causes pain, or which harmlessly vary, without increasing, pleasure. (2) We seek ataraxia or tranquillity, which sets bounds to our pleasureseeking and sends us towards sober reasoning rather than fish and sex. (3) We should value the great good of self-sufficiency, and be thankful that our nature has made it easy to satisfy those desires the satisfaction of which leads to tranquillity. We should be happy with bread and water, appreciating cheese if it is present but not distressed by its absence. (4)

This cautious and austere side to Epicureanism is likewise comprehensible, if we see it as an attempt to achieve tranquillity as our main aim. But it is nobody's idea of how to maximize pleasure. It is not surprising, therefore, that Epicurean ethics have often been thought to involve a central failure of nerve: we start pursuing pleasure but then get dramatically inhibited in this search by feelings of insecurity which direct us to tranquillity instead. The ethics seems to lack a unifying structure.

Given the state of our sources, the search for such a structure is bound to involve much interpretation of a speculative kind. This paper is the start of an attempt to understand Epicurean ethics as a coherent version of eudaimonistic ethics, and to fit the texts in the right way into the speculation. Needless to say, it is provisional and capable of much improvement. (5) 
importance of locating the virtues correctly in the happy 1ife. In these respects $M i l 1$ is far closer to the ancients than he is to the modern consequentialist tradition of utilitarianism which arguably begins with Sidgwick; and I shall use parallels from Mill, not indeed to prove claims about Epicurus, which they could hard1y do, but to show that a theory of the kind I ascribe to Epicurus is not only a coherent possibility but has actually been held.

Epicurus regards it as obvious that pleasure is for all living things an aim, indeed the primary aim; newborn children and animals seek it, and hence its pursuit depends purely on feeling and not on any false beliefs. (12) It is the primary thing which is oikeion or appropriate to us; pursuing it comes naturally. (13) But this of course does not show that pleasure is complete; even if pleasure is what is primarily appropriate to us we might still pursue it as part of a wider good. Epicurus does two things which can comprehensibly be seen as showing how pleasure can play the role of an end to which all our other ends are directed. He distinguishes two kinds of pleasure, of which only one forms our final end; and he argues that everything other than pleasure which is sought for its own sake is really sought as a means to or part of this kind of pleasure.

Kinds of pleasure

It was noted as a prominent fact about Epicureanism that it recognized two kinds of pleasure, kinetic and static. (14) Unfortunately we have no sustained discussion, but the examples in De Finibus II 9 are reasonably clear. The pleasure of drinking is kinetic, that of having drunk static. Kinetic pleasure is the pleasure you feel as lack or need is being removed. Static pleasure is what you get when pain has been removed, but it is not simply to be identified with absence of pain, since it can be varied, though not increased. (Presumably it varies according to the activity pursued when one is in the natural state; but I shall not pursue that point here.)

Static pleasure is a difficult concept, but two things about it which are not (so) controversial are important here. One is that ataraxia and aponia are static pleasures (D.L. X 136). The end of the blessed 1ife, we are told in Letter to Menoeceus 128, is bodily health and ataraxia. Notoriousiy, Epicurus says a few lines later that the beginning and end of the blessed life is pleasure, so unless we have sudden switch of final ends, ataraxia is not an alternative end but a specification of the kind of pleasure that can be our final end; and this is what we find in 131, where Epicurus says that when we cal1 pleasure the end, we mean not profligate pleasures but absence of bodily pain and mental tarachai or troubles: that is, the kind of pleasure which is elsewhere said to be static rather than kinetic. Epicurus' procedure here makes it reasonable to take ataraxia as a notion that can he1p to explicate that of static pleasure. Ataraxia is the state in which you are not hindered by pain or anything upsetting. You are functioning normally and nothing unpleasant is interfering. This is not 'tranquillity'; normal activity can be energetic and varied. Ataraxia, then, will be pleasure which is 'static', not in being a state of arrested movement but in being the pleasure of a state of functioning in which there is no interference. 
prejudice, preaching and lack of realism. Nevertheless, the strategy of appealing to human nature to ground one's concept of pleasure as our final end is in principle a good one. It compares favourably with Mill's appeal to the inclusion of 'higher' pleasures to make pleasure fit to be our u1timate aim. Mill in doing this both offends our intuitions and imports a blatant1y non-hedonic standard to modify his account of pleasure to make it the ultimate end he needs. Epicurus is, by contrast, developing our intuition that there are two different kinds of thing that we call pleasure. The common ancient objection, so prominent in Cicero, that Epicurus is using 'pleasure' in two quite distinct senses, clearly arises from ignoring the fact that the two uses of 'pleasure' are not set up arbitrarily, but are both natural uses of 'pleasure', and are connected on the one hand to the removal of need or pain, and on the other to being unimpededly in the natural state.

of course, this point about the static/kinetic pleasure distinction shows only how Epicurus can establish that there is a sense in which pleasure could plausib1y be our final good. We need to show that it is: and Epicurus does argue that pleasure (static pleasure) is not just an end, but is complete.

Pleasure and virtue.

Intuitively we reject the claim that pleasure, even static pleasure as Epicurus has presented the notion, is complete; for there are many things at which we aim for their own sakes, without having pleasure as our further aim in seeking them. Like Mill in Utilitarianism ch. 4 Epicurus concentrates on the virtues as the crucial case of this. For we want to be brave, for example, and to act bravely, for its own sake; to see pleasure as a further aim in being brave undermines our way of thinking of bravery. Virtue is the hardest case, and also one that is centrally important to how we view our lives; a theory that our final good, happiness, is pleasure must account adequately for the way we think of virtue in our lives, or it cannot succeed.

The Epicurean response to this seems straightforward enough. 'It is because of pleasure that we choose even the virtues, not for their own sake, just as we choose medicine for the sake of health' (D.L. $X 138$ ). The virtues, that is, have merely instrumental status. And there are notorious quotations from Epicurus which put the point in a very downright way. 'One should honour the noble and the virtues and that kind of stuff, if they produce pleasure; but if they don't produce it one should leave them alone'. (Usener ( $=U$ ) 70) And, more revolting1y, 'I spit on the noble and those who emptily admire it, when it doesn't make any pleasure' (U 512). (Diogenes of Oenoanda continues in this vein when in fr. 26 Chilton he rails against the stupidity of those who would make virtue our final end, not something productive of it.)

But this is not the whole story. Elsewhere we find three interesting charcterizations of the relation to virtue and pleasure. Firstiy, virtue alone is inseparable from pleasure, while other things, for example food, are separable (D.L. $X$ 138, U 506). Torquatus claims inseparability for all the virtues at Fin. I 50. Separability is a protean notion; (at least) two ideas may be in play here. I may get pleasure from food or fail to do so, but I cannot fail to get pleasure from virtue. Or: food is 
medicine and health for exactly this purpose in Utilitarianism ch. 1, evidently thinking it consistent with what he says about virtue and pleasure in ch. 4.) of course there are problems here for Epicurus, notably how he is to avoid (or render palatable) being committed to the thesis that the life of virtue is sufficient for the pleasant life; these problems are not insoluble, but there is no scope to enter in on them properly here.

If we construe what Epicurus says about pleasure and virtue overa11, then, we get the following picture. Pleasure, but not virtue, is complete- pleasure, that is, construed as static pleasure, i.e. the pleasure of unimpeded natural functioning. We seek virtue, therefore, for the sake of pleasure. But we are not. compelled to give a narrowly instrumentalist account of the value of virtue. Virtue can be sought and valued for its own sake; for living virtuous1y is required by, makes up, is part of, living pleasantly, and is not a replaceable means to it.

It is clear that to be at all plausible this relies heavily on the idea that pleasure as our final good is the condition of unimpeded natural activity, not pleasant feelings. It is also clear that very heavy reliance is being put on the notion of nature. For why ever should we think it true that living virtuously is inseparable from, entails and is entailed by, has grown to be a part of, living pleasantly, even when this is construed as living in a natural and unimpeded condition? Again, there are complexities here for Epicurus (especially given his very intellectualist and revisionary conception of the virtues).

Pleasure, then, is our final end, but this allows us to regard the virtues non-instrumentally. What happens, however, on a particular occasion when I can only exercise a virtue with clear loss of pleasure, and on 1 y get pleasure by acting against the virtue? If the value I place on justice, say, is noninstrumenta1, I will act just1y; the loss of pleasure cannot outweigh the demands of virtue. But then $I$ do not look very like someone whose final good is pleasure. If I act to get pleasure, then pleasure is clearly my final good, but by allowing considerations of pleasure to outweigh those of justice $I$ have undermined the thought that $I$ regard the virtues noninstrumenta11y.

Thir problem is most familiar to us in its utilitarian version. Again Mill and Epicurus share the problem because they both want their theory to be revisionary to the extent of establishing pleasure as our complete and final end; but conservative in that it is not to revise our non-instrumenta1 attitude to the virtues. Mill's reaction is complex and wavering; Epicurus' brief but unambiguous.

As we have seen, Epicurus insists that pleasure is our complete and final end and also that we do not regard the virtues merely as means to it. The rhetoric of Torquatus account, in Fin. I, of how we seek the virtues for the sake of pleasure is designed to combine these theses without indicating how conflict might arise. It is the Epicureans' opponents who force the issue. Prominent among Cicero's objections in Fin. II are three which are relevant to this point. Firstly, Epicureans do not mean the same as ordinary people when they talk of the virtues. The account they give of virtuous action is false, since they falsify 
that ethical theory that ordinary people are confused on the basic matter of what our final good is?

We do not know if Epicurus would have welcomed any of these defences, and here speculation may seem to have outrun the texts. Still, the speculation is sparked by ancient objections to Epicureanism, objections made by people who could read the complete texts; it is hard to think that the apparent indeterminateness of Epicurus' position here is due solely to the state of our sources. That position here seems very like Mill's, and for good reason: they both want to be revisionary about the role of pleasure without undermining our thoughts about virtue. Neither seems to take the measure of the difficulties;it is arguable that both must, to be consistent, take in the end the hard-minded position they do not want and palliate it as best they can.

I have concentrated on Epicurus' attempt to show that pleasure is complete, not just one aim we have for its own sake but ultimately the only non-instrumental aim we have. I have tried to show that, although the theory is open to serious objections, it does not collapse from lack of internal structure. It is a serious attempt to show that pleasure can be our final end and therefore a candidate for giving us the content of happiness. Whatever its problems, the theory is a unified attempt to tell us what eudaimonia is, not a recommendation to maximize pleasure coupled with unmotivated constraints on how to do this.

Epicurus' hedonism, then, is not right1y seen as applying directly to actions, telling us that the right thing to do is to calculate what will maximize pleasure in each action we perform. Rather, Epicurus is telling us that we will be happy, have the best overall life, by having pleasure as our final aim, and that we shall achieve this by living according to the virtues, i.e. by becoming a certain sort of person. Epicurean hedonism, then, is not a theory that gives us any kind of decision-procedure to apply to our actions. Rather, like other ancient ethical theories, it gives us a policy to apply to our lives to transform the kind of people we are. This policy will of course have results for how we act. But it will do so not by giving us a decision-procedure for actions, but by changing our desires. Rather than apply a calculus, 'we should confront all desires with this question: What will happen to me if what is sought by this desire comes about, and what if it does not?' (SV 71)

In the jargon, Epicurean hedonism is agent- rather than actcentred. This is an unsurprising result; ancient ethical theories differ in the content they give to eudaimonia, but share a eudaimonistic framework; and the idea that an ethical theory should release us from the effort of thinking what we should do by giving us a decision-procedure for action is a recent idea. Still, there seems to be a difficulty here in the Letter to Menoeceus passage with which I began, the one which I there said did suggest (and has to many suggested) arather different interpretation. How does this fit into the structure of Epicurean ethics as I have sketched that?

The jargon of agent- and act-centred thebries may mislead us here. The ancients were clear that an ethical theory giving one a final end for one's life would have implications for the basis of 
of morality.

\section{NOTES}

1. The Letter to Menoeceus is a short edifying exhortation; it does not reflect the scope of Epicurean ethics (containing nothing, for example, on friendship or the contractual theory of justice) and we have no reason to think that it reflects the structure of works like the Peri Telous, from which we have only short and tendentiously excerpted fragments.

2. Letter to Menoeceus 127 , KD 3, 18, 29, 30, SV 21, Fin. 45-6.

3. Letter to Menoeceus 128, 131-2. Cf. KD 17, SV 79, Usener $(=U)$ 519.

4. Letter to Menoeceus 130-1, KD 15, 21, 26, SV 59, U 202. See U 181 for the bread and water, and $U 182$ for the cheese.

5. This paper represents part of a projected work on ancient eudaimonistic ethics, covering Aristotle and later Peripatetic ethics, Epicurus and the Stoics and focussing on some basic issues that arise for a eudaimonistic ethics. Epicurus' ethics have rightly been seen in a eudaimonistic framework by $M$. Hossenfelder in 'Epicurus- hedonist ma1gre 1ui', pp. 245-263 of The Norms of Nature, edd. M. Schofie1d and G. Striker, Cambridge University. Press 1986; a1so pp. 23-39 and 102-124 of Stoa, Epikureismus und Skepsis, Band III of Geschichte der Philosophie, Munich 1985, hrsg. von W. Roed. Cf. a1so D. Pesce, Saggio su Epicuro, Bari 1974, pp. 69-72. I have also been much helped by reading excellent forthcoming work by $P$. Mitsis on Epicurean ethics, and by work by A.A. Long, especially 'Pleasure and Social Utility- the virtues of being Epicurean', pp. 283-329 of Aspects de 1a Philosophie Hellénistique, Fondation Hardt, Entretiens sur 1'antiquite classique XXXII (1986).

6. SVF III 272, 275 (definitions of autarkeia), I 187, III 49, 67, 208,685 (virtue as autarkes for happiness).

7. Self-sufficiency as a great good: Letter to Menoeceus 130-1, S.v. $44,45,68,77$, U $200,202,4 \overline{58,466,} 476$. It may be presented as a condition on our final good in a very vague fashion at Letter to Menoeceus 122: ' we should take care for the things that produce happiness, since when it is present we have everything, and when it is absent we do everything to have it.'

8. Arius Didymus ap. Stobaeus, Eclogae II 77, 16-17.

9. This occurs as a premise in an argument to show that pleasure is the highest good, and is assumed to be uncontroversia1. There are problems with the rest of the argument, but these do not affect the present point. 
concern the adequacy of Epicureanism to account for the way we think of virtue, these objections are different: we get a collection of cases which ( like the 'desert-island' cases thought up against utilitarians) provide cases where the theory under consideration would differ from ordinary morality, not just give the same answer but a less adequate account of why it is the right answer.

20. Fin. II 74-7.

21. Bailey translates 'turn to', Hicks, 'swerve aside';Arighetti has 'ti volgerai ad a1tro', Bollack 'tu t'éloignes' (La pensée du plaisir, Paris 1975). LSJ suggests 'stop short' for this passage. In any case there is a clear contrast with straightforwardly applying the principles.

22. One might, however, wonder about Letter to Menoeceus 135 , where Epicurus says that it is better to fail eulogistōs than to succeed alogistōs, since in one's actions it is better to judge right1y and fail than to succeed by chance. (There is a lacuna, but the sense is clear.) Whatever its merits as an attitude to chance, it certain1y suggests an (inadvertent?) adoption of a two-level view: it is better, for achieving the pleasant life, to dispose yourself to obtain pleasure only in a certain way (viz. with the virtue of intelligence) even though so disposing yourself will bring it about that you actually achieve less pleasure than if you had not so disposed yourself.

23. At Fin. IV 46-7 we get the Antiochan objection to the Stoics that their final good (allegedly) does not provide the springs of action. Cf. also Fin. V, 15-16: summum autem bonum si ignoretur, vivendi rationem ignorari necesse est.......cum intellegitur, quid sit bonorum extremorum et malorum, inventa vitae via est conformatioque omnium officiorum, cum exigitur, quo quidque referatur; ex quo, id quod omnes expetunt, beate vivendi ratio inveniri et comparari potest.

24. Aristocles (U 442) says that Epicureans measure pleasures only by quantity, not by quality (metreisthai gar auta tōi posói kai ou tōi poiōi.) But this is clear1y hostile interpretation, separable from anything that might be quotation. Cf. Pesce, pp. 74-5, and p. 77: 'L'ufficio della ragione pratica, lungi da 1 ísarirsi dunque ne 1 cosidet o 'utilitarismo'...per[viene]...ad una discriminazione non più meramente quantitativa, semplice calcolo algebraico di un'unica quantità omogenea nei suoi valori positivi e negativi, ma propriamente qualitativa e d'essenza. Quest'ufficio la ragione pratica assolve con le due dottrine della classificazione dei desideri e della distinzione del piacere in cinematico e catastematico.' Cf. also Gosling and Taylor, pp. 359-360.

25. As it is in the (very dissimilar) section of the Protagoras. There Socrates argues from premises which are adopted ad hominem; neither the idea that all values can be reduced to pieasure and pain, nor the idea that they can be precisely measured, need be ascribed to Socrates (still less P1ato). We should take seriously 